\title{
Isolated and mixed effects of diuron and its metabolites on biotransformation enzymes and oxidative stress response of Nile tilapia (Oreochromis niloticus)
}

\author{
Andréia Arantes Felício ${ }^{\mathrm{a}}$, Juliane Silberschmidt Freitas ${ }^{\mathrm{a}}$, Jéssica Bolpeti Scarin ${ }^{\mathrm{a}}$, \\ Luciana de Souza Ondei $^{\mathrm{b}}$, Fabrício Barreto Teresa ${ }^{\mathrm{b}}$, Daniel Schlenk ${ }^{\mathrm{c}}$, Eduardo Alves de Almeida ${ }^{\mathrm{d}, *}$ \\ a UNESP - Sao Paulo State University, Department of Chemistry and Environmental Science, Sao Jose do Rio Preto, Sao Paulo, Brazil \\ ${ }^{\mathrm{b}}$ UEG - Goias State University, University Unit of Exact and Technological Science (UnUCET), Anapolis, Goias, Brazil \\ ${ }^{\mathrm{c}}$ Department of Environmental Sciences, University of California, Riverside, USA \\ ${ }^{\mathrm{d}}$ FURB - Fundação Universidade Regional de Blumenau, Department of Natural Sciences, Blumenau, Santa Catarina, Brazil
}

\section{A R T I C L E I N F O}

\section{Keywords:}

Herbicide

Oxidative stress

Biotransformation

Fish

\begin{abstract}
A B S T R A C T
Diuron is one of the most used herbicide in the world, and its field application has been particularly increased in Brazil due to the expansion of sugarcane crops. Diuron has often been detected in freshwater ecosystems and it can be biodegraded into three main metabolites in the environment, the 3,4-dichloroaniline (DCA), 3,4-dichlorophenylurea (DCPU) and 3,4-dichlorophenyl-N-methylurea (DCPMU). Negative effects under aquatic biota are still not well established for diuron, especially when considering its presence in mixture with its different metabolites. In this study, we evaluated the effects of diuron alone or in combination with its metabolites, DCPMU, DCPU and 3,4-DCA on biochemical stress responses and biotransformation activity of the fish Oreochromis niloticus. Results showed that diuron and its metabolites caused significant but dispersed alterations in oxidative stress markers and biotransformation enzymes, except for ethoxyresorufin-O-deethylase (EROD) activity, that presented a dose-dependent increase after exposure to either diuron or its metabolites. Glutathione $S$-transferase (GST) activity was significant lower in gills after exposure to diuron metabolites, but not diuron. Diuron, DCPMU and DCA also decreased the multixenobiotic resistance (MXR) activity. Lipid peroxidation levels were increased in gill after exposure to all compounds, indicating that the original compound and diuron metabolites can induce oxidative stress in fish. The integration of all biochemical responses by the Integrated Biomarker Response (IBR) model indicated that all compounds caused significant alterations in O. niloticus, but DCPMU caused the higher alterations in both liver and gill. Our findings imply that diuron and its metabolites may impair the physiological response related to biotransformation and antioxidant activity in fish at field concentrations. Such alterations could interfere with the ability of aquatic animals to adapt to environments contaminated by agriculture.
\end{abstract}

\section{Introduction}

Brazil is the world's largest sugarcane producer in the world, covering this crop an area of about 10 million hectares, being the third largest area of cultivation in the country after soy and corn. In the years 2015/2016, sugarcane production reached 700,000,000 t (UNICA, 2016). However, the large-scale production means the overuse of pesticides for crops maintenance, which has generated concerns related to its environmental impacts on different ecosystems. Diuron (3-(3,4-dichlorophenyl)-1,1-dimethylurea) is one of the most used herbicide on sugarcane crops in Brazil and it is a frequently detected pesticides in freshwater ecosystems around the world (Morin et al., 2009; Schlenk et al., 2012). Diuron is a substituted phenylurea compound with a relatively low $\mathrm{K}_{\mathrm{OC}}$ (418-560, according to ARSUSDA, 2004) but with long hydrolysis and aqueous photolysis half-lives, which indicates a relatively low tendency to sorb to soils and sediments, making it available to the water fraction. This herbicide has moderate to high persistence in soils, with and average field dissipation half-life of 90 days, although it can be highly variable according to soil and abiotic characteristics. According to Kidd and James (1991), diuron residues may persist for

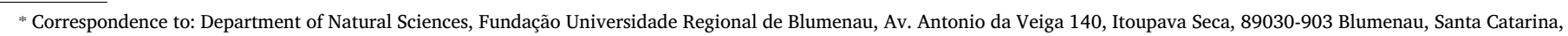
Brazil.

E-mail address: eduardoalves@furb.br (E.A. de Almeida). 
more than one year at higher application rates. Due to its low tendency to sorb to soils and its moderate persistence, diuron is therefore prone to off-site movement in surface runoff, and migration to both surface and ground water (Troiano et al., 2001; Field et al., 2003; Giacomazzi and Cochet, 2004), posing risks to aquatic organisms.

According to World Health Organization (Abass et al., 2007), diuron is classified as a slightly hazardous pesticide (class III toxicity), and considered as moderately toxic to aquatic life (ECA, 2017). In soil, diuron can be metabolized by fungi and bacteria originating three main metabolites: 3,4-dichloroaniline (DCA), 3,4-dichlorophenylurea (DCPU) and 3,4-dichlorophenyl-N-methylurea (DCPMU) (Tixier et al., 2002; Abass et al., 2007). Spontaneous hydrolysis can also occurs in aquatic environments, generating 3,4-DCA (Salvestrini et al., 2002), the main product of diuron biodegradation and the most persistent metabolite in the environment (Tixier et al., 2000). 3,4-DCA is mentioned for causing several negative effects on aquatic organisms, such as alterations on morphological (Scheil et al., 2009; Mhadhbi and Beiras, 2012), biochemical (Sánchez-Muros et al., 2013), physiological (Miranda et al., 2008; Scheil et al., 2009; Freitas et al., 2016) and behavioral (Saglio and Trijasse, 1998) parameters. Studies have also shown that diuron metabolites (especially DCPMU and DCPU) have anti-androgenic and estrogenic effects in male and female Nile tilapia (Pereira et al., 2015, 2016; Felício et al., 2016). Although clear evidences of negative effects of diuron and its metabolites on endocrine system of fish, there are no studies regarding the effects of these compounds in biochemical parameters often used as classical pollutant biomarkers, such as the biotransformation enzymes and oxidative stress parameters, which are also important to clarify physiological aspects involved in the defense response of aquatic organisms against environmental pollutants.

The evaluation of biochemical alterations in environmental monitoring studies is a common practice to indicate the exposure of aquatic organisms to pollutants and it can be used as an early stage alert for detection of environmental contamination. Biotransformation enzymes are considered relevant biochemical parameters evaluating chemical disturbance on animal health, since they contribute to the detoxification process, minimizing the deleterious effects of the xenobiotics in the organisms. Cytochrome P450 isoforms, glutathione $S$-transferase (GST) and multixenobiotic resistance (MXR) efflux proteins are involved in the biotransformation and elimination of xenobiotics from cells and they usually act as one of the first cellular response to xenobiotic input (Van der Oost et al., 2003; Luckenbach et al., 2004; Klobučar et al., 2010). Intoxication can also increase oxygen consumption, increasing the rate of the generation of reactive oxygen species (ROS) that can lead to oxidative lesions to biomolecules and oxidative stress. In response to increased ROS production, cells alters their antioxidant defenses, which includes the enzymes superoxide dismutase (SOD), glutathione peroxidase (GPx), catalase (CAT) and glutathione reductase (GR), as well as glucose-6-phosphate dehydrogenase (G6PDH), which provides NADPH for the GR-catalyzed regeneration of glutathione from glutathione disulfide and for cytochrome P450-catalyzed biontransformation reactions (Stegeman et al., 1992; Lopez-Torres et al., 1993). If the generation of ROS surpasses the antioxidant capacity, an oxidative stress condition takes place, leading to the oxidation of key cellular macromolecules such as lipids, proteins, nucleic acids and carbohydrates (Van der Oost et al., 2003). One common biomarker of oxidative lesion to lipids is malondialdehyde (MDA), an aldehyde that is a by-product derived from the decomposition of lipid hydroperoxides formed by the oxidation of polyunsaturated fatty acids (Van der Oost et al., 2003; Almeida et al., 2005, 2007). MDA is a highly reactive molecule (Trivic and Leskuvac, 1994) that can react with other macromolecules (Bartels, 2001), including nucleic acids, generating mutagenic DNA adducts (Van der Oost et al., 2003; Almeida et al., 2005, 2007), and therefore must be eliminated from cells. The enzyme aldehyde dehydrogenase (ALDH) can act metabolizing MDA and other lipid peroxidation-derived aldehydes, assisting in cellular detoxification process (Nakazono et al., 2000; Kirch et al., 2001, 2004).

Considering the importance of the biotransformation enzymes and oxidative stress parameters as indicators of health status of aquatic animals in natural systems, we are interested in investigating how diuron and its metabolites can impair physiological mechanisms of fish at environmental relevant concentrations. As mentioned before, diuron has relatively high persistence in the environment, which is likely to occur in combination with other degradation products, such as its metabolites DCPMU, DCPU and 3,4-DCA. Thus, this study evaluated the effects of diuron and its metabolites alone, or in mixture, on the activities of enzymes related to biotransformation process (ethoxyresorufin-O-deethylase, EROD, benzyloxyresorufin-O-deethylase, BROD, and pentoxyresorufin-O-deethylase, PROD, GST and MXR) and oxidative stress response (activities of SOD, CAT, GPx, GR, G6PDH, ALDH and MDA levels) in gills and livers of Nile tilapia. Biological responses triggered by chemical exposure were assessed based on individual biomarkers and on an integrative index, the integrated biomarker response (IBR, Beliaeff and Burgeot, 2002). We hypothesize that diuron and its metabolites may increase detoxification activity of biotransformation enzymes and Mxr levels as consequence of intoxication process caused by chemical exposure. We also suggest that antioxidant response and lipid peroxidation will be associated to biotransformation performance, since ROS production can be rised by intoxication process, which would stimulate antioxidant enzymes and on the opposite way, increase lipid peroxidation as consequence of damage of cellular components. The information brought by this study is relevant to better clarify how aquatic animals are dealing with pesticides presence in their environments.

\section{Material and methods}

\subsection{Chemical}

All chemicals were ordered from Sidma-Aldrich Chemical Co (ST. Louis, Mo), including Diuron, DCPMU, DCPU and DCA (> 98\% pure).

\subsection{Test organisms}

Male Nile tilapias (Oreochromis niloticus) were obtained from the Aquiculture Center of the Sao Paulo State University - UNESP. The weight and length of tilapias used in this study were, $77.81 \pm 12.98 \mathrm{~g}$ and $13.68 \pm 0.83 \mathrm{~cm}$ (mean \pm standard deviation), respectively. Before exposures, the animals were acclimatized and maintained in the laboratory under ideal conditions of temperature, $\mathrm{pH}$ and oxygen $\left(28^{\circ} \mathrm{C}, \mathrm{pH} 7.5-8.0\right)$ during 7 days, and fed to satiation with commercial fish food (commercial pellets for tropical fish, 32\% crude protein Guabi-Pira/Brazil). Our experiments had permission from Ethics Committee from Animal Use in research of the Sao Paulo State University (CEUA-IBILCE/UNESP) (71/2013).

\subsection{Exposure experiments}

After acclimatization, 66 fish were separated in eleven groups, with six fish per group $(\mathrm{N}=6)$. The animals were maintained in $17 \mathrm{~L}$ individual aquariums (one fish per aquarium) with dechlorinated water and controlled temperature $\left(25 \pm 1{ }^{\circ} \mathrm{C}\right)$, constantly aerated and kept in a 12:12 h light-dark cycle. For isolated exposures, the animals were exposed to each individual compound - diuron, DCPMU, DCU or 3,4DCA - at two different concentrations of 40 and $200 \mathrm{ng} \mathrm{L}^{-1}$, totalizing eight individual exposures. For the mixtures, fish were exposed to a mix containing diuron and its three metabolites (diuron + DCPMU + DCPU + DCA) at concentrations of $10 \mathrm{ng} \mathrm{L}^{-1}$ and $50 \mathrm{ng} \mathrm{L}^{-1}$ each, and totalizing two combined exposures. The concentrations were chosen based on mean diuron values found in contaminated aquatic environments (up to 160 ng/L) (Köck-Schulmeyera et al., 2013; Masiá et al., 2015), and based on previous studies done by our research group on the effects 
Table 1

Concentration of diuron, DCPMU, DCPU and 3,4-DCA measured in water of the treatments.

\begin{tabular}{|c|c|c|c|c|}
\hline Treatment / Group & Expected concentration $\left(\mathrm{ng} \mathrm{L}^{-1}\right)$ & Measured concentration (ng $\mathrm{L}^{-1}$ ) & pH & Dissolved $\left[\mathrm{NH}_{3}\right]$ \\
\hline Control & 0 & $<\mathrm{LD}$ & $7.9 \pm 0.06$ & $0.19 \pm 0.07$ \\
\hline Diuron $40 \mathrm{ng} \mathrm{L}^{-1}$ & 40 & $57.35 \pm 0.48$ & $7.9 \pm 0.04$ & $0.22 \pm 0.07$ \\
\hline Diuron $200 \mathrm{ng} \mathrm{L}^{-1}$ & 200 & $284.01 \pm 0.34$ & $7.9 \pm 0.02$ & $0.26 \pm 0.06$ \\
\hline DCPMU $40 \mathrm{ng} \mathrm{L}^{-1}$ & 40 & $16.53 \pm 3.37$ & $7.9 \pm 0.10$ & $0.31 \pm 0.09$ \\
\hline DCPMU $200 \mathrm{ng} \mathrm{L}^{-1}$ & 200 & $88.50 \pm 1.37$ & $7.8 \pm 0.25$ & $0.22 \pm 0.11$ \\
\hline DCPU $40 \mathrm{ng} \mathrm{L}^{-1}$ & 40 & $23.85 \pm 0.21$ & $7.8 \pm 0.10$ & $0.31 \pm 0.15$ \\
\hline DCPU $200 \mathrm{ng} \mathrm{L}^{-1}$ & 200 & $231.04 \pm 0.72$ & $7.7 \pm 0.13$ & $0.22 \pm 0.05$ \\
\hline DCA $40 \mathrm{ng} \mathrm{L}^{-1}$ & 40 & $47.21 \pm 0.47$ & $7.7 \pm 0.11$ & $0.25 \pm 0.08$ \\
\hline DCA $200 \mathrm{ng} \mathrm{L}^{-1}$ & 200 & $131.23 \pm 0.20$ & $7.8 \pm 0.14$ & $0.35 \pm 0.16$ \\
\hline \multirow[t]{4}{*}{ Mixture of $10 \mathrm{ng} \mathrm{L}^{-1}$} & 10 (diuron) & $10.91 \pm 0.48$ & $7.8 \pm 0.05$ & $0.59 \pm 0.28$ \\
\hline & 10 (DCPMU) & $47.15 \pm 3.13$ & & \\
\hline & 10 (DCPU) & $5.94 \pm 2.76$ & & \\
\hline & 10 (DCA) & $23.75 \pm 0.25$ & & \\
\hline \multirow[t]{4}{*}{ Mixture of $50 \mathrm{ng} \mathrm{L}^{-1}$} & 50 (diuron) & $17.69 \pm 0.60$ & $7.8 \pm 0.08$ & $0.28 \pm 0.13$ \\
\hline & 50 (DCPMU) & $49.58 \pm 1.20$ & & \\
\hline & 50 (DCPU) & $82.80 \pm 0.64$ & & \\
\hline & 50 (DCA) & $29.23 \pm 1.36$ & & \\
\hline
\end{tabular}

$\mathrm{LD}=$ Limit of detection.

of diuron and metabolites in the levels of sexual hormones and gametogenesis (Felício et al., 2016; Pereira et al., 2015, 2016; Boscolo et al., 2017). Control group was maintained under the same conditions as the treatments; however no chemicals were added into the aquariums. Each compound was diluted $(50 \mu \mathrm{L})$ in the aquariums at the respective concentration from a stock solution previously weighted and dissolved in acetone to give the desired concentration in a volume of $50 \mu \mathrm{L}$ of the stock solution. The corresponding volume of solvent was also added in the control group. The water and chemicals were totally changed every 2 days, by replacing the animals to another aquarium with the same treatments. The same procedure of water change was done with the control group. Animals were fed with ration for tropical fish (GuabiPira/Brazil) corresponding to $3 \%$ of biomass at each water change. After seven days of exposure, all fish were collected, anesthetized by immersion in a benzocaine solution $\left(90 \mathrm{mg} \mathrm{L}^{-1}\right)$ and their livers and gills were removed and stored in $-80{ }^{\circ} \mathrm{C}$. Water $\mathrm{pH}$ and $\mathrm{NH}_{3}$ levels (Table 1) were monitored throughout the experiment. In the first day, water samples $(10 \mathrm{~mL})$ were collected from each aquarium just before placing the fish into the aquariums, in order to check chemical concentrations.

\subsection{Chemical analyses}

Concentrations of diuron, DCPMU, DCPU and 3,4-DCA in water from the different experimental aquariums were checked by HPLC in the first day, just before adding the fish into the aquariums. The HPLC system (Shimadzu Corporation, Kyoto, Japan) consisted of one CBM20A communication bus module, two LC20AD-XR pumps, one CTO20AR column oven, and one SPDM20A photodiodearray (PDA) detector. The column used was a Shimadzu Shim-Pack XR-ODS $(2.0 \times$ $100.0 \mathrm{~mm}, 2.2 \mu \mathrm{m}$ particle size, $8 \mathrm{~nm}$ pore size). PDA detector wavelength was adjusted between 200 and $600 \mathrm{~nm}$ for all analyses, and the compounds were quantified at $250 \mathrm{~nm}$. The mobile phase consisted of acetonitrile and water (40:60, v/v), and was isocratically pumped at a flow rate of $0.5 \mathrm{~mL} \mathrm{~L}^{-1}$. Column oven temperature was set to $40{ }^{\circ} \mathrm{C}$. The water sample ( $50 \mu \mathrm{L}$ of water) was injected into the HPLC through an autosampler (Shimadzu, Nexera XR, SIL-20AC XR) and monitored during $5 \mathrm{~min}$. Retention times for diuron, DCPMU, DCPU and DCA were, respectively 2.9, 2.2, 1.5 and $3.6 \mathrm{~min}$. Chromatogram peaks were identified and quantified using LAB Solution 5.71 software (Shimadzu Corporation). The calculation of concentration of each compound was based on a calibration curve, previously constructed by injecting authentic standards into the HPLC system $\left(10-1000 \mathrm{ng} \mathrm{L}^{-1}\right)$. The limit of detection for all the compounds was $10 \mathrm{ng} \mathrm{L}^{-1}$.

\subsection{Biochemical analyses}

\subsubsection{Enzymatic assay and protein quantification}

Liver and gill were homogenized (1:4, weight/volume) in Tris buffer $0.05 \mathrm{M}$ (pH 7.4) containing sucrose $0.005 \mathrm{M}, \mathrm{KCl} 0.015 \mathrm{M}$ and protease inhibitor (phenylmethanesulfonylfluoride - PMSF) $0.001 \mathrm{M}$. The homogenized samples were centrifuged at $10,000 \mathrm{~g}$ for $20 \mathrm{~min}$ at $4{ }^{\circ} \mathrm{C}$, and the supernatant fraction was collected and re-centrifuged at $50,000 \mathrm{~g}$ for additional $60 \mathrm{~min}$ at $4{ }^{\circ} \mathrm{C}$. The second supernatant fraction was used for SOD, CAT, GPx, GST, G6PDH and GR assays, while the pellet, suspended in $100 \mu \mathrm{L}$ of Tris buffer $0.1 \mathrm{M}$ (pH 7.5), containing EDTA $0.001 \mathrm{M}$, dithiothreitol (DTT) $0.001 \mathrm{M}, \mathrm{KCl} 0.1 \mathrm{M}$ and glycerol $20 \%$, was used for EROD, BROD and PROD assays.

SOD activity was evaluated by the inhibition of cytochrome $\mathrm{C}$ reduction in the presence of hypoxanthine/xanthine oxidase $\mathrm{O}_{2}{ }^{*-}$ generator system at $550 \mathrm{~nm}$ (McCord and Fridovich, 1969). CAT activity was quantified at $240 \mathrm{~nm}$ by $\mathrm{H}_{2} \mathrm{O}_{2}$ decomposition according Beutler (1975). GPx activity was assayed using the oxidation of NADPH (linked to GSSG reduction by excess glutathione reductase) at $340 \mathrm{~nm}$, and using t-butyl hydroperoxide as substrate, as described by Sies et al. (1979). GST activity was quantified at $340 \mathrm{~nm}$ using reduced glutathione (GSH) and 1-chloro-2,4-dinitrobenzene (CDNB) as substrate, according Keen et al. (1976). GR activity was measured using the consumption of NADPH at $340 \mathrm{~nm}$ in the presence of oxidized glutathione (GSSG), monitoring the reduction of GSSG to GSH by GR, according Carlberg and Mannervik (1985). G6PDH activity was quantified according the production of NADPH through consumption of NADP at $340 \mathrm{~nm}$, using glucose-6-phosphate as substrate and $\mathrm{Mg}_{2}{ }^{+}$ (from $\mathrm{MgCl}_{2}^{-}$) as co-factor, according Glock and McLean (1953).

ALDH activity was measured only in the liver because the activity was very low in the gills. The samples were homogenized in potassium phosphate buffer $30 \mathrm{mM}, \mathrm{pH} 7.5$ (1:5; v: v) and centrifuged at 10,000g for $10 \mathrm{~min}$. After homogenization, the samples were analyzed using the method described by Sydow et al. (2004), by monitoring the formation of NADH at $340 \mathrm{~nm}$ for $10 \mathrm{~min}$ in Tri-HCl buffer $100 \mathrm{mM}$, pH 8.5, containing $1 \mathrm{mM} \mathrm{NAD}{ }^{+}, 1 \mathrm{mM}$ pyrazole and $1 \mathrm{mM}$ acetaldehyde as substrate.

EROD, BROD and PROD activity were measured according to Burke and Mayer (1974), by monitoring the conversion of the substrates 7ethoxyresorufin, 7-benzyloxyresorufin and 7-pentoxyresorufin, respectively, into the fluorescent product resorufin $\left(\lambda_{\text {excit }}=537 \mathrm{~nm}\right.$, $\lambda_{\text {emis }}=583 \mathrm{~nm}$ ) during $3 \mathrm{~min}$, in the presence of NADPH. Protein amount in samples was quantified by the method of Bradford (1976). 
Table 2

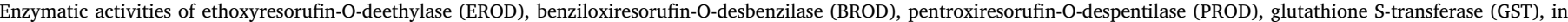

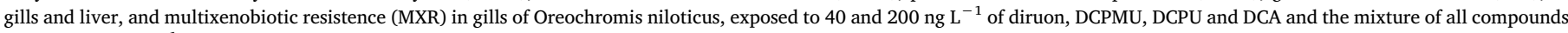
in 10 and $50 \mathrm{ng} \mathrm{L}^{-1}$ of each compound for 7 days.

\begin{tabular}{|c|c|c|c|c|c|c|c|}
\hline \multirow[t]{2}{*}{ Tissue } & \multirow[t]{2}{*}{ Treatment } & \multirow{2}{*}{$\begin{array}{l}\text { Concentration } \\
\left(\mathrm{ng} \mathrm{L}^{-1}\right)\end{array}$} & \multicolumn{5}{|c|}{ Biochemical biomarkers } \\
\hline & & & EROD $^{A}$ & BROD $^{\text {A }}$ & PROD $^{A}$ & $\mathbf{G S T}^{\mathrm{B}}$ & $\mathbf{M X R}^{\mathrm{C}}$ \\
\hline \multirow[t]{11}{*}{ Gill } & Control & 0 & $11.7 \pm 1.9$ & $2.8 \pm 1.44$ & $14.8 \pm 4.6$ & $12.3 \pm 1.0$ & $2.7 \pm 0.18$ \\
\hline & Diuron & 40 & $10.6 \pm 2.8$ & $1.1 \pm 1.5$ & $15.7 \pm 1.5$ & $12.0 \pm 1.2$ & $2.6 \pm 0.06$ \\
\hline & & 200 & $15.9 \pm 3.3$ & $6.3 \pm 1.1^{*}$ & $13.3 \pm 2.6$ & $11.5 \pm 1.0$ & $2.0 \pm 0.14$ \\
\hline & DCPMU & 40 & $15.0 \pm 1.1$ & $6.2 \pm 0.7$ & $22.8 \pm 2.4$ & $9.5 \pm 0.5^{*}$ & $1.7 \pm 0.09$ \\
\hline & & 200 & $20.0 \pm 0.5^{*}$ & $7.5 \pm 0.8$ & $14.0 \pm 6.7$ & $9.3 \pm 0.6$ & $3.0 \pm 0.23$ \\
\hline & DCPU & 40 & $20.6 \pm 1.4^{*}$ & $2.5 \pm 1.0$ & $19.9 \pm 4.8$ & $10.1 \pm 0.3^{*}$ & $3.1 \pm 0.20$ \\
\hline & & 200 & $13.2 \pm 2.5$ & $5.7 \pm 2.5$ & $21.6 \pm 7.9$ & $10.2 \pm 0.7$ & $2.7 \pm 0.27$ \\
\hline & DCA & 40 & $16.5 \pm 3.3$ & $3.6 \pm 1.6$ & $17.4 \pm 6.7$ & $10.0 \pm 0.7^{*}$ & $1.9 \pm 0.14$ \\
\hline & & 200 & $14.1 \pm 1.7$ & $2.6 \pm 0.6$ & $27.8 \pm 1.6$ & $9.0 \pm 0.5^{*}$ & $2.2 \pm 0.10$ \\
\hline & Mixture & 10 & $13.8 \pm 1.3$ & $2.7 \pm 0.6$ & $18.3 \pm 1.6$ & $8.4 \pm 0.3^{*}$ & $2.3 \pm 0.07$ \\
\hline & & 50 & $5.3 \pm 1.0^{*}$ & $0.08 \pm 0.1$ & $19.4 \pm 1.8$ & $9.8 \pm 0.5^{*}$ & $2.9 \pm 0.06$ \\
\hline \multirow[t]{11}{*}{ Liver } & Control & 0 & $8.6 \pm 1.9$ & $15.7 \pm 12.8$ & $12.5 \pm 3.0$ & $43.1 \pm 8.3$ & - \\
\hline & Diuron & 40 & $103.5 \pm 31.9^{*}$ & $9.2 \pm 2.5$ & $17.5 \pm 0.9$ & $56.6 \pm 15.1$ & - \\
\hline & & 200 & $92.9 \pm 28.1^{*}$ & $12.5 \pm 7.5$ & $14.0 \pm 2.7$ & $44.5 \pm 17.1$ & - \\
\hline & DCPMU & 40 & $46.7 \pm 17.2^{*}$ & $5.7 \pm 6.2$ & $10.7 \pm 0.9$ & $43.0 \pm 15.9$ & - \\
\hline & & 200 & $108.4 \pm 22.8^{*}$ & $16.0 \pm 17.5$ & $8.9 \pm 1.9$ & $44.9 \pm 7.7$ & - \\
\hline & DCPU & 40 & $63.1 \pm 6.8^{*}$ & $17.3 \pm 12.2$ & $7.8 \pm 1.5$ & $46.0 \pm 12.2$ & - \\
\hline & & 200 & $82.7 \pm 24.1^{*}$ & $17.0 \pm 10.1$ & $8.8 \pm 1.9$ & $51.4 \pm 9.3$ & - \\
\hline & DCA & 40 & $47.1 \pm 9.6^{*}$ & $13.2 \pm 11.0$ & $17.8 \pm 1.3$ & $43.5 \pm 14.0$ & - \\
\hline & & 200 & $148.9 \pm 44.1^{*}$ & $25.6 \pm 12.4$ & $19.0 \pm 5.0$ & $38.2 \pm 11.7$ & - \\
\hline & Mixture & 10 & $77.1 \pm 16.2^{*}$ & $14.8 \pm 10.0$ & $6.5 \pm 1.8$ & $32.2 \pm 13.1$ & - \\
\hline & & 50 & $182.5 \pm 40.7^{*}$ & $20.8 \pm 13.1$ & $19.9 \pm 3.0^{*}$ & $41.3 \pm 10.3$ & - \\
\hline
\end{tabular}

(-) No result in this tissue.

All data are mean \pm standard deviation;

${ }^{\text {A }} \mathrm{pmol} / \mathrm{min} / \mathrm{mg}$ protein;

${ }^{\mathrm{B}} \mathrm{mU} / \mathrm{mg}$ protein.

${ }^{\mathrm{C}} \mu \mathrm{M}$.

* Statistical difference compared to the control group $(\mathrm{p}<0.05)$

\subsubsection{Multixenobiotic resistance (MXR) activity}

MXR analyses were performed in the gills according Luckenbach et al. (2004), with some alterations. Fragments $\left(1 \mathrm{~cm}^{2}\right)$ were cut out from the gills, washed with pure water (to eliminate blood and mucus), dried and then incubated in pure water with $1 \mu \mathrm{M}$ of rhodamine B (RB) for $90 \mathrm{~min}$ at $20^{\circ} \mathrm{C}$ in the dark. After this period, the fragments were washed with pure water, dried in filter paper and then placed in $550 \mu \mathrm{L}$ of butanol. Samples were then sonicated for $30 \mathrm{~s}$ to extract intracellular $\mathrm{RB}$ and centrifuged for $10 \mathrm{~min}$ at $14,000 \mathrm{~g}$. The amount RB in supernatant was determined in a spectrofluorimeter (Perkin-Elmer, Victor), using and emission of $545 \mathrm{~nm}$ and excitation of $575 \mathrm{~nm}$. Calculations were based on a RB calibration curve.

\subsection{Lipid peroxidation}

Levels of lipid peroxidation in liver and gills were estimated by measuring the product formed from the reaction of malondialdehyde (MDA) and thiobarbituric acid (TBA) by HPLC coupled to photodiodearray (PDA) detector (Almeida et al., 2003, 2004). The HPLC system (Shimadzu Corporation, Kyoto, Japan) was the same used for chemical analyses of the water. The column used was a Shimadzu ShimPack XR-ODS $(3.0 \times 100.0 \mathrm{~mm}, 2.2 \mu \mathrm{m}$ particle size, $8 \mathrm{~nm}$ pore size $)$. For this analysis, $100 \mathrm{mg}$ of the sample was homogenized in $0.3 \mathrm{~mL}$ of Tris buffer $0.1 \mathrm{M}$ (pH 8.0). Then $40 \mathrm{mg}$ of TBA was dissolved in $10 \mathrm{~mL}$ of $\mathrm{HCl} 0.2 \mathrm{M}$ and $0.3 \mathrm{~mL}$ of this solution was added to each sample. This mixture was heated at $90{ }^{\circ} \mathrm{C}$ for $40 \mathrm{~min}$. After that $1 \mathrm{~mL}$ of n-butanol was added and samples were centrifuged at $1500 \mathrm{~g}$ for $3 \mathrm{~min}$ to extract the MDA-TBA derivative. The supernatant was collected and quantified by HPLC at $532 \mathrm{~nm}$, in terms of a malondialdehyde (MDA) standard calibration curve that had been previously prepared (with tetramethoxypropane - TMP) using the same procedure used of the sample.

\subsection{Statistical analyzes}

Statistical analyzes were performed using the software Statistica 8 . The normality and homogeneity of the data were tested by ShapiroWilk and Levene test, respectively. For parametric data, one-way ANOVA was used followed by the Tukey post-hoc test. For nonparametric data, the Kruskal-Wallis test was used, followed by multiple comparisons of mean ranks. Values of $\mathrm{P}<0.05$ were considered as a reference to assign statistical significance (Zar et al., 1999). To analyze the integrative effect of all biomarkers we used the "Integrated Biomarker Response" test (IBR), described by Beliaeff and Burgeot (2002), with modifications according Sanchez et al. (2013) ("Integrated Biomarker Response version 2"- IBRv2). These calculations are based on reference deviation concept. The IBRv2 test use control results to determine the values of other groups. The IBR number is the sum of the deviation of each parameter. The "star plot" was done with the average of the value of each treatment and contributed to observe how much the treated group differed from the control.

\section{Results}

\subsection{Chemical analyses}

The measured concentrations of diuron, DCPMU, DCPU and DCA in each experimental group are depicted in Table 1. The concentrations were near the expected, despite some slight discrepancies, especially for the group exposed to DCPMU at $200 \mathrm{ng} \mathrm{L}^{-1}$. No mortality was observed for $O$. niloticus after seven days of exposure.

\subsection{Biotransformation enzymes}

EROD activity was increased in gill after exposure to DCPMU $200 \mathrm{ng} \mathrm{L}^{-1}$ and DCPU $40 \mathrm{ng} \mathrm{L}^{-1}$, however it was decreased after 
exposure to the mixture of contaminants at the higher concentration when compared to the control group ( $\mathrm{p}=0.0076)$. In liver, EROD activity increased in all treatments when compared to the control group, with an observed increase of the enzymatic activity with the increase of the exposure concentration ( $p=0.0047$ ) (Table 2).

BROD activity was only increased in gill after exposure to diuron and DCPMU at $200 \mathrm{ng} \mathrm{L}^{-1}$ compared to control group ( $\left.\mathrm{p}=0.018\right)$. No alteration in BROD activity was observed in the liver ( $p=0.09)$. PROD activity was unchanged in gill after exposure in all experimental groups $(p=0.28)$. In liver, PROD increased after exposure to mixture of contaminants at $50 \mathrm{ng} \mathrm{L}^{-1}$ when compared to the control $(\mathrm{p}=0.001)$ (Table 2).

GST activity in tilapia gills was decreased after seven days of exposure to DCPMU 40 and $200 \mathrm{ng} \mathrm{L}^{-1}$, DCPU $40 \mathrm{ng} \mathrm{L}^{-1}$, 3,4- DCA $40 \mathrm{ng} \mathrm{L}^{-1}$ and $200 \mathrm{ng} \mathrm{L}^{-1}$, and mixture of contaminants at both concentrations of 10 and $50 \mathrm{ng} \mathrm{L}^{-1}(\mathrm{p}=0.01)$ (Table 2). With respect to MXR activity, a significant decrease was observed in RB efflux in gill of fish treated with Diuron $200 \mathrm{ng} \mathrm{L}^{-1}$, DCPMU $40 \mathrm{ng} \mathrm{L}^{-1}$, 3,4-DCA 40 and $200 \mathrm{ng} \mathrm{L}^{-1}$, and the mixture of all compounds at $10 \mathrm{ng} \mathrm{L}^{-1}$ (p $<0.001$ ) (Table 2).

\subsection{Oxidative stress response}

Activities of the antioxidant enzymes SOD, CAT, GPx, GR and G6PDH of fish from all experimental groups are show in Table 3. SOD activity was not altered in gills after exposure to any isolated contaminants or mixtures $(\mathrm{p}=0.13)$. In liver, SOD activity was increased after exposure to DCPMU $200 \mathrm{ng} \mathrm{L}^{-1}$, DCPU $40 \mathrm{ng} \mathrm{L}^{-1}$ and to the mixture of compounds at $10 \mathrm{ng} \mathrm{L}^{-1}$ when compared to the control group ( $\mathrm{p}=0.007)$. CAT was decreased in gills after exposure to diuron $40 \mathrm{ng} \mathrm{L}^{-1}$, DCPMU $40 \mathrm{ng} \mathrm{L}^{-1}$, DCPU $200 \mathrm{ng} \mathrm{L}^{-1}$, 3,4-DCA $40 \mathrm{ng} \mathrm{L}^{-1}$ and the mixture of contaminants at $10 \mathrm{ng} \mathrm{L}^{-1}$, ( $\left.\mathrm{p}=0.005\right)$. In liver, CAT activity was increased after exposure to 3,4-DCA $200 \mathrm{ng} \mathrm{L}^{-1}$ and the mixture of contaminants for both 10 and $50 \mathrm{ng} \mathrm{L}^{-1}(\mathrm{p}<0.001)$. GPx activity increased in gills after exposure to all compounds, ( $\mathrm{p}=$ 0.008 ), however no changes were observed in the liver $(\mathrm{p}=0.5)$. GR activity in gills was increased after exposure to diuron $200 \mathrm{ng} \mathrm{L}^{-1}$, DCPMU 40 and $200 \mathrm{ng} \mathrm{L}^{-1}$, and decreased after exposure to DCPU 40 and $200 \mathrm{ng} \mathrm{L}^{-1}, 3,4$-DCA at $200 \mathrm{nd}^{-\mathrm{L}^{-1}}$ and mixture of contaminants at 10 and $50 \mathrm{ng} \mathrm{L}^{-1}(\mathrm{p}<0.001)$, while no changes were observed in the liver $(\mathrm{p}=0.47)$. G6PDH activity was decreased in gills after exposure to DCPU $200 \mathrm{ng} \mathrm{L}^{-1}$ and 3,4-DCA $40 \mathrm{ng} \mathrm{L}^{-1}$ compared to the control group ( $\mathrm{p}=0.007$ ). On an opposite way, G6PDH was increased in liver after exposure to DCPMU $200 \mathrm{ng} \mathrm{L}^{-1}, 3$,4-DCA 40 and $200 \mathrm{ng} \mathrm{L}^{-1}$ and mixture of contaminants at $50 \mathrm{ng} \mathrm{L}^{-1}(\mathrm{p}<0.001)$ (Table 3). Hepatic ALDH activity in tilapia was increased after exposure to DCPMU $200 \mathrm{ng} \mathrm{L}^{-1} \quad(\mathrm{p}<0.001)$ and to $3,4-\mathrm{DCA} 40 \mathrm{ng} \mathrm{L}^{-1}(\mathrm{p}=0.007)$ (Table 3).

Lipid peroxidation levels were higher in gills of fish exposed to diuron $40 \mathrm{ng} \mathrm{L}^{-1}$, DCPMU 40 and $200 \mathrm{ng} \mathrm{L}^{-1}$, DCPU 40 and $200 \mathrm{ng} \mathrm{L}^{-1}$, 3,4-DCA 40 and $200 \mathrm{ng} \mathrm{L}^{-1}$ and the mixture of contaminants at 10 and $50 \mathrm{ng} \mathrm{L}^{-1}(\mathrm{p}<0.001)$. In liver, no alteration was observed after exposure $(\mathrm{p}=0.06)$ (Table 3$)$.

\subsection{Integrated biomarker response}

All treatments caused significant increases on IBR scores in gill tissues. The gills of animals exposed to DCPMU 40 and $200 \mathrm{ng} \mathrm{L}^{-1}$ presented the greatest increase from the control group (Fig. 1). In the liver, we observed that the metabolite DCPU did not influence IBR index for both concentrations. All other compounds increased IBR values in liver, excepted by diuron at concentration of $200 \mathrm{ng} / \mathrm{L}^{-1}$ and DCPMU at $40 \mathrm{ng} / \mathrm{L}^{-1}$ (Fig. 2). Similarly to that observed in gills, fish exposed to DCPMU $200 \mathrm{ng} \mathrm{L}^{-1}$ presented the greatest increase from the control group (Fig. 2). The "star plots" representations for gills (Fig. 3) and liver (Fig. 4) indicate how each individual biomarker contributed

Table 3

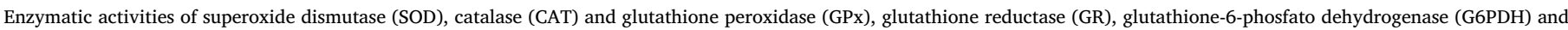

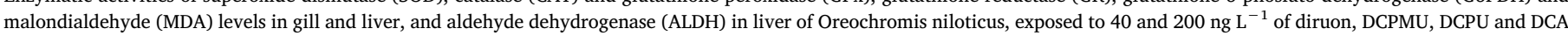
and the mixture of all compounds in 10 and $50 \mathrm{ng} \mathrm{L}^{-1}$ of each compound for 7 days.

\begin{tabular}{|c|c|c|c|c|c|c|c|c|c|}
\hline \multirow[t]{2}{*}{ Tissue } & \multirow[t]{2}{*}{ Treatment } & \multirow{2}{*}{$\begin{array}{l}\text { Concentration } \\
\left(\mathrm{ng} \mathrm{L}^{-1}\right)\end{array}$} & \multicolumn{7}{|c|}{ Biochemical biomarkers } \\
\hline & & & SOD $^{\mathrm{C}}$ & CAT $^{\mathrm{C}}$ & $\mathbf{G P x}^{\mathrm{B}}$ & $\mathbf{G R}^{\mathrm{B}}$ & G6PDH $^{\mathrm{C}}$ & MDA $^{\mathrm{D}}$ & $\mathbf{A L D H}^{\mathrm{B}}$ \\
\hline \multirow[t]{11}{*}{ Gill } & Control & 0 & $4.90 \pm 0.54$ & $660 \pm 12.7$ & $1.0 \pm 0.13$ & $0.58 \pm 0.04$ & $0.71 \pm 0.03$ & $10.4 \pm 1.5$ & - \\
\hline & Diuron & 40 & $6.15 \pm 0.54$ & $582 \pm 20.3^{*}$ & $2.5 \pm 0.11^{*}$ & $0.69 \pm 0.03$ & $0.60 \pm 0.04$ & $17.4 \pm 2.4^{*}$ & - \\
\hline & & 200 & $5.10 \pm 0.25$ & $662 \pm 9.8$ & $2.6 \pm 0.27^{*}$ & $0.76 \pm 0.06^{*}$ & $0.58 \pm 0.03$ & $15.2 \pm 3.1^{*}$ & - \\
\hline & DCPMU & 40 & $5.88 \pm 0.46$ & $561 \pm 30.2^{*}$ & $2.3 \pm 0.39^{*}$ & $0.82 \pm 0.02^{*}$ & $0.72 \pm 0.08$ & $22.2 \pm 1.6^{*}$ & - \\
\hline & & 200 & $5.33 \pm 0.20$ & $605 \pm 32.4$ & $2.4 \pm 0.14$ & $0.75 \pm 0.01^{*}$ & $0.64 \pm 0.07$ & $22.0 \pm 2.2^{*}$ & - \\
\hline & DCPU & 40 & $5.91 \pm 0.44$ & $649 \pm 24.2$ & $2.1 \pm 0.09^{*}$ & $0.22 \pm 0.07^{*}$ & $0.64 \pm 0.02$ & $16.9 \pm 1.7^{*}$ & - \\
\hline & & 200 & $5.02 \pm 0.32$ & $584 \pm 10.8^{*}$ & $2.1 \pm 0.08^{* \prime}$ & $0.17 \pm 0.03^{*}$ & $0.57 \pm 0.02$ & $19.0 \pm 2.9^{* k}$ & - \\
\hline & DCA & 40 & $4.81 \pm 0.23$ & $547 \pm 5.3^{*}$ & $2.1 \pm 0.13^{*}$ & $0.33 \pm 0.01^{*}$ & $0.49 \pm 0.05^{*}$ & $14.2 \pm 1.8^{*}$ & - \\
\hline & & 200 & $4.92 \pm 0.25$ & $632 \pm 30.1$ & $2.2 \pm 0.09^{*}$ & $0.24 \pm 0.05^{*}$ & $0.80 \pm 0.03$ & $13.7 \pm 1.9^{*}$ & - \\
\hline & Mixture & 10 & $4.81 \pm 0.25$ & $544 \pm 45.8^{*}$ & $2.1 \pm 0.05^{*}$ & $0.27 \pm 0.09^{*}$ & $0.69 \pm 0.01$ & $15.1 \pm 1.1^{*}$ & - \\
\hline & & 50 & $4.96 \pm 0.52$ & $621 \pm 29.4$ & $1.9 \pm 0.34^{*}$ & $0.06 \pm 0.02^{*}$ & $0.62 \pm 0.05$ & $18.4 \pm 2.7^{*}$ & - \\
\hline \multirow[t]{11}{*}{ Liver } & Control & 0 & $9.7 \pm 2.1$ & $12.1 \pm 2.2$ & $17.0 \pm 4.0$ & $9.4 \pm 3.1$ & $0.47 \pm 0.12$ & $19.3 \pm 1.8$ & $3.43 \pm 1.35$ \\
\hline & Diuron & 40 & $9.8 \pm 1.7$ & $10.6 \pm 2.7$ & $18.3 \pm 4.6$ & $9.6 \pm 3.9$ & $0.64 \pm 0.10$ & $11.3 \pm 1.4$ & $1.54 \pm 0.03$ \\
\hline & & 200 & $9.3 \pm 1.9$ & $10.6 \pm 2.0$ & $14.3 \pm 5.4$ & $11.6 \pm 4.9$ & $0.69 \pm 0.31$ & $13.6 \pm 1.9$ & $3.82 \pm 0.09$ \\
\hline & DCPMU & 40 & $9.1 \pm 3.0$ & $11.2 \pm 2.5$ & $16.7 \pm 7.2$ & $9.3 \pm 4.6$ & $0.70 \pm 0.28$ & $12.7 \pm 2.9$ & $4.75 \pm 0.59$ \\
\hline & & 200 & $13.0 \pm 0.6^{*}$ & $10.3 \pm 2.8$ & $18.4 \pm 4.3$ & $13.1 \pm 2.9$ & $0.85 \pm 0.15^{*}$ & $14.4 \pm 2.6$ & $10.84 \pm 2.07^{*}$ \\
\hline & DCPU & 40 & $12.2 \pm 2.5$ & $10.2 \pm 3.1$ & $15.7 \pm 3.4$ & $10.0 \pm 2.1$ & $0.65 \pm 0.15$ & $12.3 \pm 2.6$ & $6.05 \pm 0.23$ \\
\hline & & 200 & $11.2 \pm 0.5$ & $12.2 \pm 3.0$ & $17.9 \pm 4.3$ & $11.5 \pm 1.4$ & $0.64 \pm 0.13$ & $17.1 \pm 1.2$ & $5.96 \pm 1.36$ \\
\hline & DCA & 40 & $11.0 \pm 0.9$ & $13.4 \pm 1.7$ & $19.6 \pm 7.6$ & $9.4 \pm 2.0$ & $0.99 \pm 0.29$ & $11.1 \pm 1.4$ & $7.38 \pm 1.28$ \\
\hline & & 200 & $11.5 \pm 2.0$ & $14.1 \pm 0.9^{*}$ & $16.4 \pm 4.2$ & $9.8 \pm 2.5$ & $1.03 \pm 0.15^{*}$ & $16.7 \pm 2.8$ & $3.71 \pm 0.98$ \\
\hline & Mixture & 10 & $14.3 \pm 0.6^{*}$ & $14.5 \pm 3.3^{*}$ & $19.8 \pm 6.6$ & $10.1 \pm 2.4$ & $0.63 \pm 0.22$ & $16.9 \pm 4.4$ & $5.85 \pm 0.12$ \\
\hline & & 50 & $9.5 \pm 0.8$ & $16.4 \pm 2.0^{* \prime}$ & $16.7 \pm 5.1$ & $11.9 \pm 2.7$ & $1.11 \pm 0.17^{*}$ & $13.2 \pm 0.7$ & $4.60 \pm 0.22$ \\
\hline
\end{tabular}

All data are mean \pm standard deviation;

(-) No result in this tissue. ${ }^{\mathrm{E}} \mathrm{pM} / \mathrm{mg}$ tissue.

в $\mathrm{mU} / \mathrm{mg}$ protein;

${ }^{\mathrm{C}} \mathrm{U} / \mathrm{mg}$ protein;

D nmol/mg tissue;

* Statistical difference compared to the control group $(\mathrm{p}<0.05)$ 


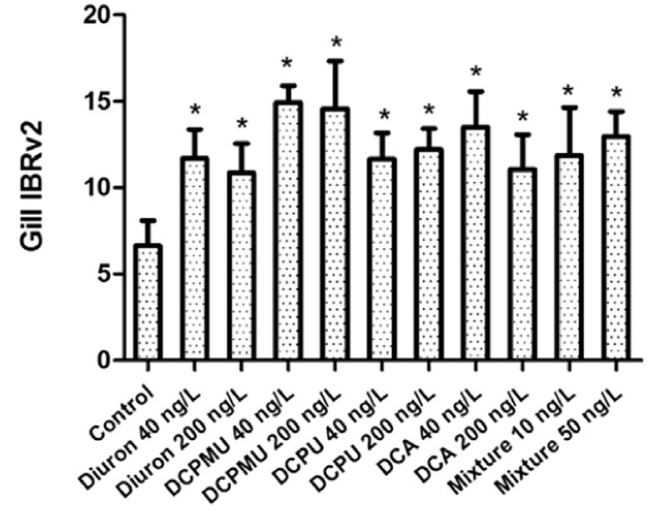

Fig. 1. Integrated biomarker response (IBR) index summarizing the responses of biochemical biomarkers to diuron, DCPMU, DCPU, DCA and the mixtures in gills of fish O. niloticus. Asterisk (*) indicates statistical difference compared to the control group $(\mathrm{p}<0.05)$.

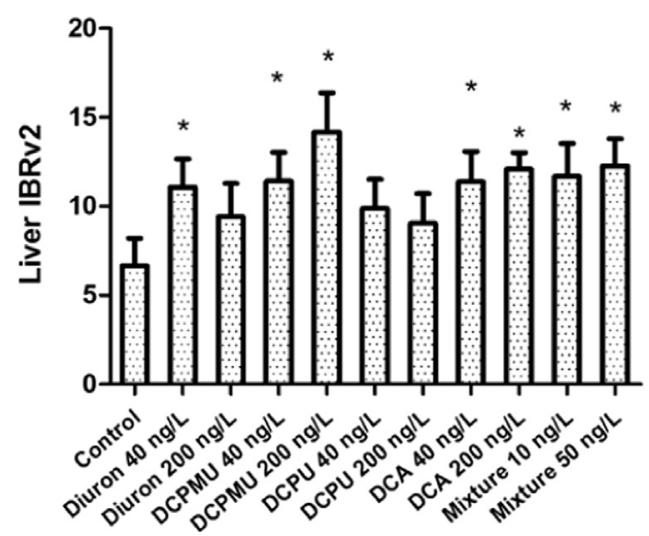

Fig. 2. Integrated biomarker response (IBR) index summarizing the responses of biochemical biomarkers to diuron, DCPMU, DCPU, DCA and the mixtures in liver of fish O. niloticus. Asterisk $(*)$ indicates statistical difference compared to the control group $(\mathrm{p}<0.05)$.

for the IBR value obtained for each experimental group.

\section{Discussion}

Diuron and its main metabolite, 3,4-DCA, have been shown to exert toxic effects in aquatic organisms (Ensenbach et al., 1996; Guilhermino et al., 1998; Sosak-Swiderska et al., 1998; Girling et al., 2000; Tixier et al., 2001; Osano et al., 2002; Pereira et al., 2015). However, information about the toxicity of other intermediate metabolites, such as DCPMU and DCPU, which participate in the 3,4-DCA formation pathway, are still limited for aquatic and other organisms, although some studies have pointed their higher toxicity in relation to diuron (Tixier et al., 2000). Until the moment, other effects than endocrine disruption caused by diuron and its metabolites on fish physiology have not been demonstrated, especially when they are present in mixture conditions, which makes it difficult to interpret how these animals are adapting to diuron contamination in water bodies. Understanding how aquatic organisms deal with contaminants in their environments is extremely urgent in a context where the toxicity of most agrochemicals used in crops in Brazil is still unknown for many species. In this study, we showed that diuron and its metabolites, in both isolated or mixture conditions impair biotransformation enzymes and antioxidant response of fish, leading the organisms to a condition of oxidative stress, which was evidenced by increased lipid oxidation.

In general, both diuron and metabolites caused significant but disperse alterations in oxidative stress parameters and biotransformation enzymes. In addition, no clear dose-response relationship was observed, except that EROD activity was increased in the liver of fish after exposure to all treatments. This increase in EROD suggests the involvement of this enzyme in the metabolism of diuron and all metabolites, and could account to indicate it as a suitable biomarker for diuron or diuron metabolite exposure in fish. In accordance to our result, Zhao et al. (2006) demonstrated that diuron is capable to bind the AhR receptor, thus activating CYP1A in mammals. Previously, it was also demonstrated that diuron was able to increase EROD activity in rats, corroborating the involvement of this enzyme in diuron metabolism (Schoket and Vincze, 1990). In contrary, BROD and PROD presented very disperse response in our study, and they were apparently not involved in the metabolism of the studied compounds. In the gills, the significant decrease in GST activity in those fish exposed to diuron metabolites, but not diuron, could indicate a higher negative impact of diuron metabolites compared to the parental compound on fish health, since decreased GST activity turns the fish less efficient on biotransformation processes. Indeed, diuron, DCPMU and DCA caused a decrease in MXR activity, also indicating a negative impact of these compounds in defense mechanisms of the gills against intoxication. MXR is a protein efflux transporter that keeps toxicants out of the cells, protecting the cells from environmental contaminants (Ferreira et al., 2014). The inhibition of MXR as seen in this study can compromise the effectiveness of the defense system, since toxic substances that would normally be excluded, will remain in the cell and exert their toxic effect (Luckenbach et al., 2004; Fisher et al., 2013; Ferreira et al., 2014).

With respect to oxidative stress markers, it was clear that all the compounds triggered oxidative stress in the gills, since all of them caused a marked increase in MDA levels in this tissue. Nevertheless, no such increase was observed in the liver, which indicates the gills as a more susceptible organ to oxidative stress. It is well known that several classes of pesticides are able to induce peroxidation of membrane components in response to a non-compensatory action of antioxidant system against excessive amount of ROS, produced under stress conditions (Regoli and Giuliani, 2014). In this study, we observed that antioxidant enzyme responses were very puzzled for all enzymes, except for GPx activity in gills that increased after exposure to all treatments, also indicating a probable increase in ROS production that lead to increased MDA levels. The remaining antioxidant enzymes presented very disperse responses, without any dose-response relationships. We also observed a varied response between the different studied tissues. For example G6PDH activity in the gill was decreased only after exposure to the higher concentration of DCPU and the lower concentration of 3,4-DCA, while in the liver this enzyme was increased only in those animals exposed to the higher concentration of DCPMU, the mixture of all compounds and to both concentration of 3,4-DCA. SOD activity was increased only in the gills of animals exposed to the higher concentration of DCPMU and to the lower concentration of the mixture. CAT activity also showed random decreases in the gill, and increases in the liver, and GR presented a significant increase in the gills of animals exposed to both concentrations of diuron and DCPMU, while this enzyme was lower in the same organ of animals exposed to the remaining treatments. Finally, ALDH was increased only in the gills of animals exposed to the higher concentration of DCPMU and to the lower concentration of DCA, showing no correlation with MDA levels.

Increases in antioxidant enzymes are generally a response to increases in ROS production, while decreases can be a result of an inhibitory effect of the contaminant along the exposure time (Regoli and Giuliani, 2014). The lack of any dose-response or conserved response of antioxidant enzymes to the tested contaminants observed in this study indicates that the different compounds exert distinct mechanisms in the analyzed organs without a clear pattern. Nevertheless, it should be considered that the contaminants interfered in the antioxidant defense enzymes of the fish, which could indicate the instigation of ROS production in the toxicity mechanism of all tested compounds. Although less evident in the liver due to the lack of alterations in MDA levels, this hypothesis can be sustained by the significant increase in GPx activity 

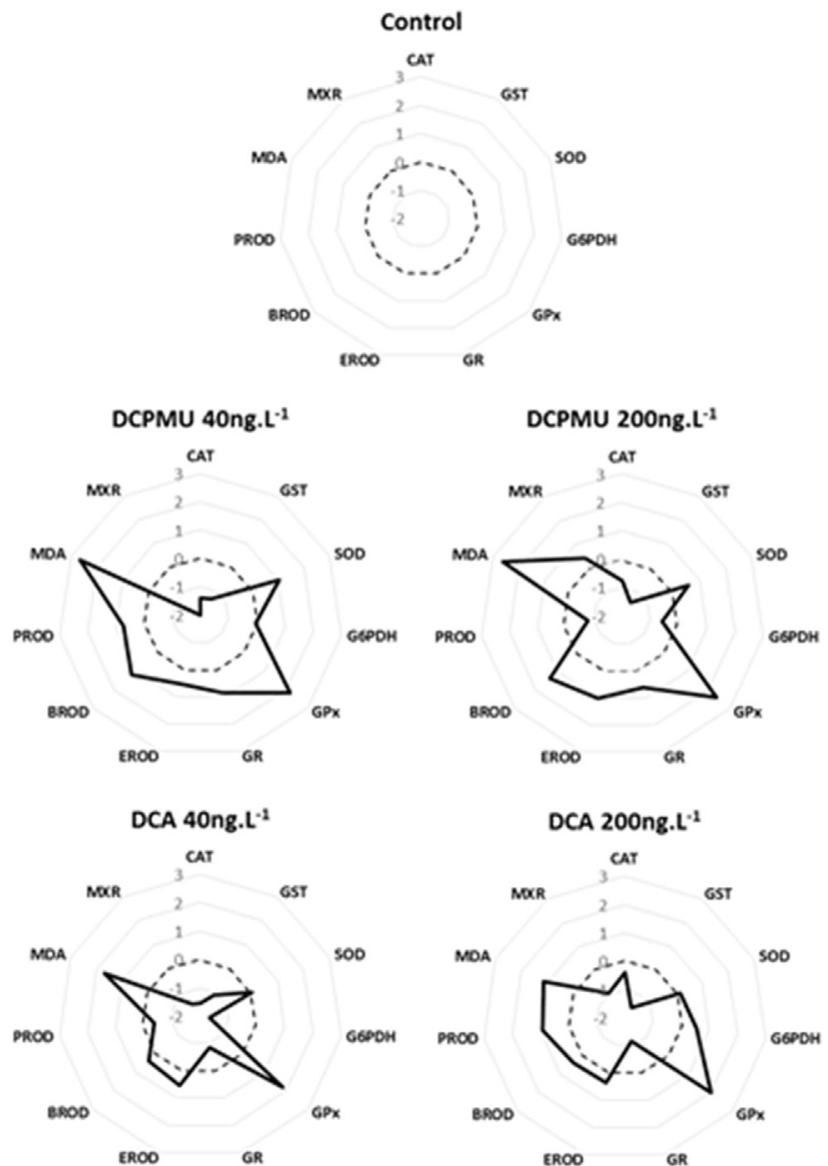
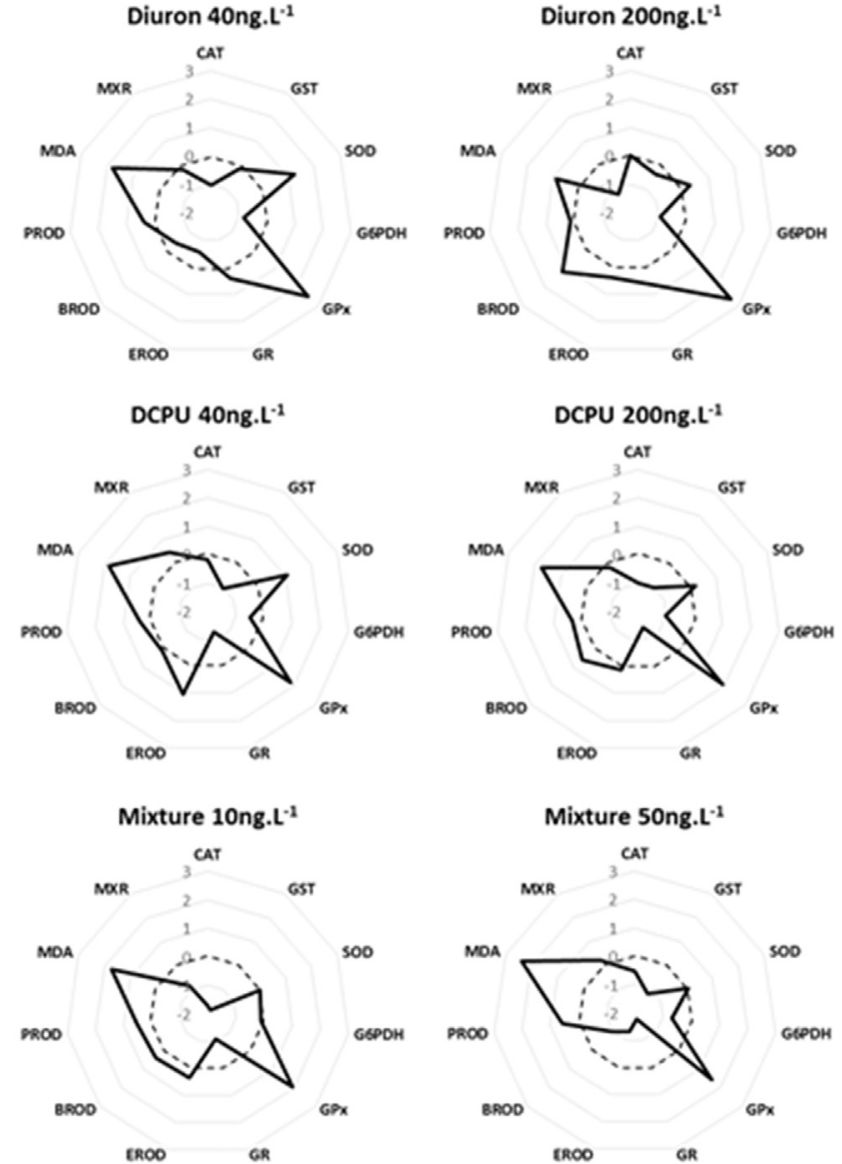

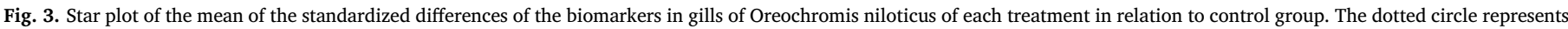

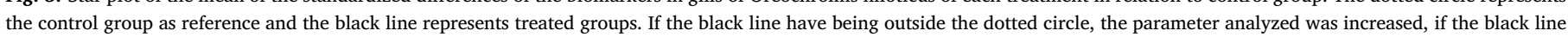
have being inside the dotted circle, the parameter was decreased, compared to the control group.

and MDA levels in the gills.

Similarly to those responses observed on biotransformation enzymes, the analysis of the individual oxidative stress parameters also indicated that diuron metabolites had a more prominent action in the antioxidant defense system of fish than the original compound diuron. These responses were especially evident in animals exposed to the metabolite DCPMU, which impaired most of the enzymes in liver and gills. These results were confirmed by the applied IBR model, which distinguished the effects of DCPMU as the most pronounced in relation to the control group. Previous studies with $O$. niloticus also showed that DCPMU, but in the same proportion as the other intermediates metabolites, caused prominent anti-androgenic and estrogenic effects compared to diuron (Pereira et al., 2015, 2016). This evidences the relevance of studying intermediate metabolites, and not only the final product or the original compound, in monitoring studies involving pesticides. In addition, exposure of fish to mixture conditions apparently did not cause additive effects or interaction effects on antioxidant response or oxidative stress, even for those exposed to DCPMU. Synergistic effects could account for this lack of response, since contaminant concentrations in the mixture were lower than that used for exposure to the isolated compound.

Taking into account the two sets of biomarkers analyzed, oxidative stress markers and biotransformation enzymes, we noted that EROD in the liver and GPx activity and MDA levels in the gill presented a clear response to the studied contaminants, which would suggest these parameters as general biomarkers for diuron and metabolites monitoring studies. Although the disperse responses of the other biomarkers (BROD, PROD, MXR, SOD, CAT, GR and ALDH), it actually represented an advantage for a better attribution of general effects of the contaminants on fish health in a integrated approach.

\section{Conclusion}

Our data demonstrated that diuron and its biodegradation metabolites at environmental relevant concentrations are able to alter different physiological response of fish, evidenced by changes of biochemical parameters of oxidative stress and biotransformation. These findings corroborate with other previous studies that showed that diuron metabolites can be as deleterious as diuron (Saglio and Trijasse, 1998; Miranda et al., 2008; Scheil et al., 2009; Mhadhbi and Beiras, 2012; Sánchez-Muros et al., 2013; Pereira et al., 2015, 2016; Felício et al., 2016). In fact, analysis of individual and integrated parameters pointed that diuron metabolites may promote more evidenced changes on antioxidant response and biotransformation process than the original compound. These results were especially prominent for DCPMU, which was noted as the main compound causing alterations in exposed fish in an integrated biomarker analysis. We also observed that EROD in the liver, and GPx and MDA levels in the gills were especially responsive to the treatments, being considered the parameters with greater responsiveness to the general effects of all contaminants. Our results bring important issues about the using of different biomarkers on monitoring studies approach. It evidences that a variety of tools not only demonstrate the most appropriate biomarkers that should be applied for exposure investigations, but they also contribute to the understanding of which pathways environmental contaminants take to harm the health of aquatic organisms. 


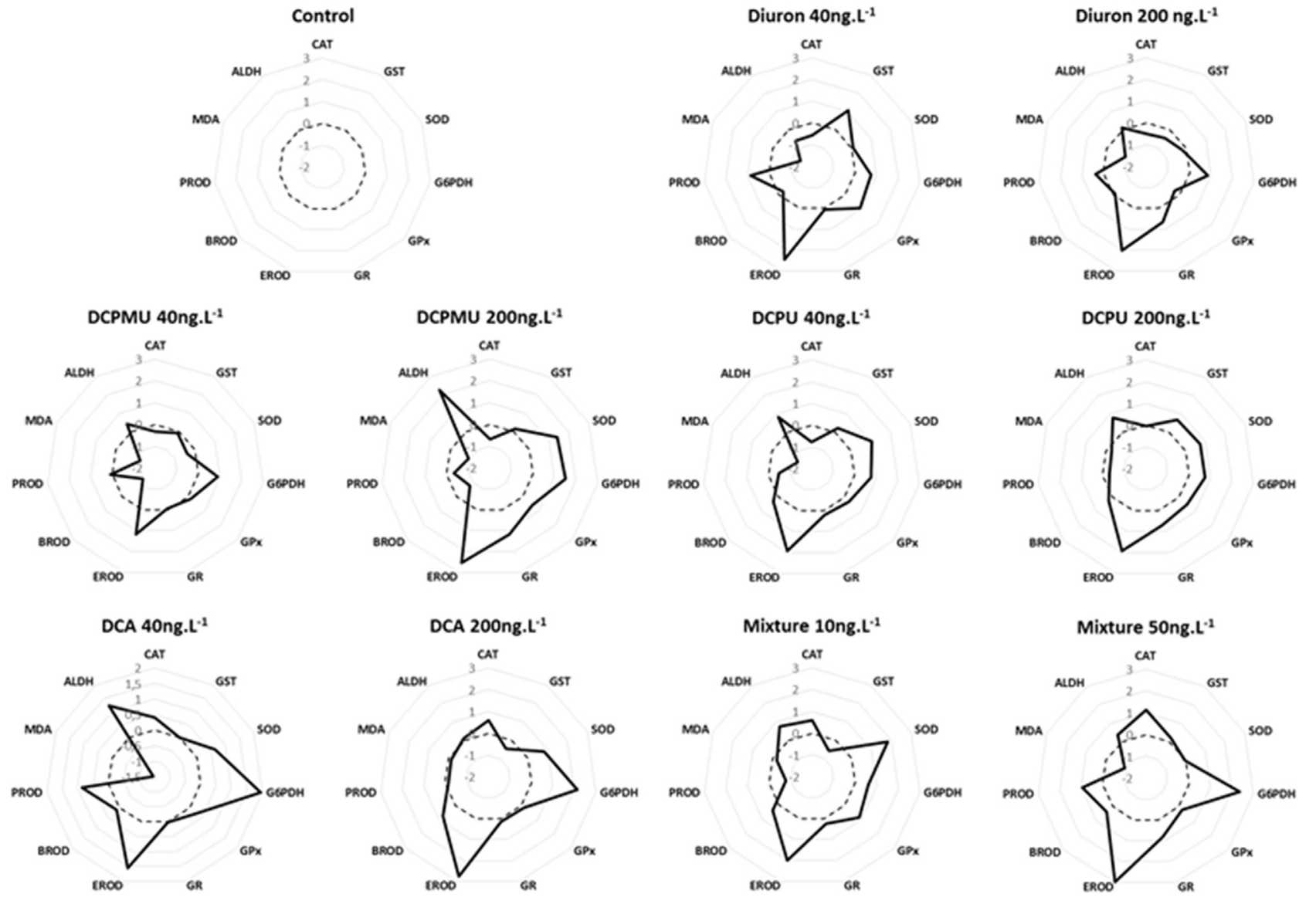

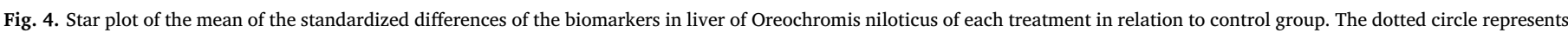

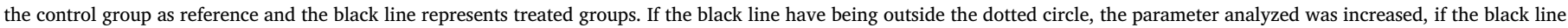
have being inside the dotted circle, the parameter was decreased, compared to the control group.

\section{Acknowledgements}

This work was supported by the "Fundação de Amparo à Pesquisa do Estado de São Paulo - FAPESP" (2011/52061-8, 2014/18825-9, 2013/16948-3), the "Coordenação de Aperfeiçoamento de Pessoal de Nível Superior" and the "Conselho Nacional de Desenvolvimento Cientiíco e Tecnológico" (CNPq, Brazil, 473245/2009-4). FBT and EAA are recipients of CNPq productivity fellowship (302158/2015 and 307603/2014-8, respectively).

\section{Conflict of interest statement}

The authors disclose any potential sources of conflict of interest.

\section{References}

Abass, K., Reponen, P., Turpeinen, M., Jalonen, J., Pelkonen, O., 2007. Characterization of diuron $\mathrm{N}$-demethylation by mammalian hepatic microsomes and c-DNA expressed human cytochrome P450 enzymes. Drug Metab. Dispos. 35, 1634-1641.

Almeida, E.A., Bainy, A.C.D., Dafre, A.L., Gomes, O.F., Medeiros, M.H.G., Di Mascio, P., 2005. Oxidative stress in digestive gland and gill of the brown mussel (Perna perna) exposed to air and re-submersed. J. Exp. Mar. Biol. Ecol. 318, 21-30.

Almeida, E.A., Bainy, A.C.D., Loureiro, A.P.M., Martinez, G.R., Miyamoto, S., Onuki, J., Barbosa, L.F., Garcia, C.C.M., Prado, F.M., Ronsein, G.E., Sigolo, C.A., Brochini, C.B., Martins, A.M.G., Medeiros, M.H.G., Di Mascio, P., 2007. Oxidative stress in Perna perna and other bivalves as indicators of environmental stress in the Brazilian marine environment: antioxidants, lipid peroxidation and DNA damage. Comp. Biochem. Physiol. Part A: Mol. Integr. Physiol. 146, 588-600.

Almeida, E.A., Marques, S.A., Klitzke, C.F., Bainy, A.C.D., Medeiros, M.H.G., Di Mascio, P., Loureiro, A.P.M., 2003. DNA damage in digestive gland and mantle tissue of the mussel Perna perna. Comp. Biochem. Physiol. - Part C: Toxicol. Pharmacol. 135, 295-303.

Almeida, E.A., Miyamoto, S., Bainy, A.C., Medeiros, M.H., Di Mascio, P., 2004. Protective effect of phospholipid hydroperoxide glutathione peroxidase (PHGPx) against lipid peroxidation in mussels Perna perna exposed to different metals. Mar. Pollut. Bull. 49, 386-392.

ARSUSDA, 2004. The Agricultural Research Services Pesticide Properties Database. Department of Agriculture, U.S. (Online) (Available). 〈http://www.arsusda.gov/ acsl/services/ppdb/>.

Bartels, D., 2001. Targeting detoxification pathways: an efficient approach to obtain plants with multiples stress toletance? Trends Plant Sci. 6, 284-286.

Beliaeff, B., Burgeot, T., 2002. Integrated biomarker response: a useful tool for ecological risk assessment. Environ. Toxicol. Chem. 21, 1316-1322.

Bradford, M.M., 1976. A rapid and sensitive method for the quantitation of microgram quantities of protein utilizing the principle of protein-dye binding. Anal. Biochem. 72 248-254.

Beutler, E., 1975. Red Cell Metabolism: A Manual of Biochemical Methods. Grune \& Stratton, New York.

Boscolo, C.N.P., Pereira, T.S.B., Batalhão, I.G., Dourado, P.L.R., Schlenk, D., de Almeida, E.A., 2018. Diuron metabolites act as endocrine disruptors and alter aggressive behaviour in Nile tilapia (Oreochromis niloticus). Chemosphere 191, 832-838. http://dx. doi.org/10.1016/j.chemosphere.2017.10.009.

Burke, M.D., Mayer, R.T., 1974. Ethoxyresorufin: direct fluorimetric assay of a microsomal O-dealkylation which is preferentially inducible by 3 - methylcholanthrene. Drug Metab. Dispos. 2, 583-588.

Carlberg, I., Mannervik, B., 1985. Glutathione reductase. Methods Enzymol. 113, 484-490.

ECA, European Chemical Agency, 2017. 〈https://echa.europa.eu/substanceinformation/-/substanceinfo/100.005.778>.

Ensenbach, U., Hryk, R., Nagel, R., 1996. Kinetics of 3,4-dichloroaniline in several fish species exposed to different types of water. Chemosphere 32, 1643-1654.

Felício, A.A., Crago, J., Maryoung, L.A., Almeida, E.A., Schlenk, D., 2016. Effects of alkylphenols on the biotransformation of diuron andenzymes involved in the synthesis and clearance of sex steroids injuvenile male tilapia (Oreochromus mossambica). Aquat. Toxicol. 180, 345-352

Ferreira, M., Costa, J., Reis-Henriques, M.A., 2014. ABC transportes in fish species: a review. Front. Physiol. 5.

Field, J.A., Reed, R.L., Sawyer, T.E., Griffith, S.M., Wigington, P.J., 2003. Diuron occurrence and distribution in soil and surface and ground water associated with grass seed production. J. Environ. Qual. 32, 171-179.

Fisher, S., Klüver, N., Burkhardt-Medicke, K., Pietsch, M., Schmidt, A., Wellner, P., 
Schirmer, K., Luckenbach, T., 2013. Abcb4 acts as multixenobiotic transporter and active barrier against chemical uptake in zebrafish (Danio rerio) embryos. BMC Biol. 11, 69. http://dx.doi.org/10.1186/1741-7007-11-69.

Freitas, J.S., Kupsco, A., Diamante, G., Felicio, A.A., Almeida, E.A., Schlenk, D., 2016. Influence of temperature on the thyroidogenic effects of diuron and its metabolite 3,4-DCA in tadpoles of the American Bullfrog (Lithobates catesbeianus). Environ. Sci. Technol. 50 (23), 13095-13104. http://dx.doi.org/10.1021/acs.est.6b04076. Epub 2016 Nov 9.

Giacomazzi, S., Cochet, N., 2004. Environmental impact of diuron transformation: a review. Chemosphere 56, 1021-1032.

Girling, A.E., Tattersfield, L., Mitchell, G.C., Crossland, N.O., Pascoe, D., Blockwell, S.J., Maund, S.J., Taylor, E.J., Wenzel, A., Janssen, C.R., Juttner, I., 2000. Derivation of predicted no-effect concentrations for lindane, 3,4-dichloroaniline, atrazine, and copper. Ecotoxicol. Environ. Saf. 46, 148-162.

Glock, G.E., McLean, P., 1953. Further studies on the properties and assay of glucose 6phosphate dehydrogenase and 6-phosphogluconate dehydrogenase of rat liver. Biochem. J. 55 (3), 400-408.

Guilhermino, L., Soares, A.M.V.M.A.P.C., Lopes, M.C., 1998. Acute effects of 3,4-dichloroaniline on blood of male wistar rats. Chemosphere 37, 619-632.

Keen, J.H., Habig, W.H., Jakoby, W.B., 1976. Mechanism for the several activities of the glutathione S-transferases. J. Biol. Chem. 244, 3714-3721.

Kidd, H., James, D., 1991. The Agrochemicals Handbook, Third ed. Royal Society of Chemistry Information Services, Cambridge.

Kirch, H.H., Nair, A., Bartels, D., 2001. Novel ABA-dehydration-inducible aldehyde dehydrogenase genes isolated from the resurrection plant Craterostigna plantagineum and Arabidopsis thaliana. Plant J. 28, 555-567.

Kirch, H.H., Bartels, D., Wei, Y., Schnable, P.S., Wood, A.J., 2004. The ALDH gene superfamily of Arabidopsis thalian. Trends Plant Sci. 9, 371-377.

Klobučar, R., Žaja, R., Franjević, D., Brozoviae, A., Smital, T., 2010. Presence of ecotoxicologically relevant Pgp and MRP transcripts and proteins in cyprinid fish. Arch. Ind. Hyg. Toxicol. J. 61, 175-182. http://dx.doi.org/10.2478/10004-1254-61-2010.

Köck-Schulmeyera, M., Villagrasa, M., Alda, M.L., Céspedes-Sánchez, R., Frances Ventura, F., Barcelóa, D., 2013. Occurrence and behavior of pesticides in wastewater treatment plants and their environmental impact. Sci. Total Environ. 458, 466-476.

Lopez-Torres, M., Perez-Campo, R., Cadenas, S., Rojas, C., Barja, G., 1993. A comparative research of free radicals in vertebrates-II. non-enzymatic antioxidants and oxidative stress. Comp. Biochem. Physiol. 105, 757-763.

Luckenbach, T., Corsi, I., EPEL, D., 2004. Fatal attraction: synthetic musk fragances compromisse multixenobiotic defense systems in mussels. Mar. Environ. Res. 58, 215-219.

Masiá, A., Campo, J., Navarro-Ortega, A., Barceló, D., Picó, Y., 2015. Pesticide monitoring in the basin of Llobregat River (Catalonia, Spain) and comparison with historical data. Sci. Total Environ. 503, 68-78.

McCord, J.M., Fridovich, I., 1969. Superoxide dismutase. An enzymic function for erythrocuprein (hemocuprein). J. Biol. Chem. 244, 6049-6055.

Mhadhbi, L., Beiras, R., 2012. Acute toxicity of seven selected pesticides (Alachlor, Atrazine, Dieldrin, Diuron, Pirimiphos-Methyl, Chlorpyrifos, Diazinon) to the marine fish (Turbot, Psetta maxima). Water Air Soil Pollut. 223, 5917-5930.

Miranda, A.L., Roche, H., Randi, M.A.F., Menezes, M.L., Oliveira, C.A., 2008. Bioaccumulation of chlorinated pesticides and PCBs in the tropical freshwater fish Hoplias malabaricus: histopathological, physiological, and immunological findings. Environ. Int. 34, 939-949.

Morin, S., Bottin, M., Mazzella, N., Macary, F., Delmas, F., Winterton, P., Coste, M., 2009. Linking diatom community structure to pesticide input as evaluated through a spatial contamination potential (Phytopixal): a case study in the Neste river system (SouthWest France). Aquat. Toxicol. 94 (1), 28-39.

Nakazono, M., Tsuji, H., Li, Y., Saisho, D., Arimura, S., Tsutsumi, N., Hirai, A., 2000. Expression of a gene encoding mitochondrial aldehyde dehydrogenase in rice increases under submerged conditions. Plant Physiol. 124, 587-598.

Osano, O., Admiraal, W., Klamer, H.J., Pastor, D., Bleeker, E.A., 2002. Comparative toxic and genotoxic effects of chloroacetanilides, formamidines and their degradation products on Vibrio fischeri and Chironomus riparius. Environ. Pollut. 119, 195-202.

Pereira, T.S.B., Boscolo, C.N.P., Felício, A.A., Batlouni, S.R., Schlenk, D., Almeida, E.A., 2016. Estrogenic activities of diuron metabolites in female Nile tilapia (Oreochromis niloticus). Chemosphere 146, 497-502.
Pereira, T.S.B., Boscolo, C.N.P., Silva, D.G.H., Batlouni, S.R., Schlenk, D., Almeida, E.D., 2015. Anti-androgenic activities of diuron and its metabolites in male Nile tilapia (Oreochromis niloticus). Aquat. Toxicol. 164, 10-15.

Regoli, R., Giuliani, M.E., 2014. Oxidative pathways of chemical toxicity and oxidative stress biomarkers in marine organisms. Mar. Environ. Res. 93, 106-117.

Saglio, P., Trijasse, S., 1998. Behavioral responses to atrazine and diuron in goldfish. Arch. Environ. Contam. Toxicol. J. 35, 484-491.

Salvestrini, S., Di Cerbo, P., Capasso, S., 2002. Kinetics of the chemical degradation of diuron. Chemosphere 48, 69-73.

Sanchez, W., Burgeot, T., Porcher, J.M., 2013. A novel "Integrated Biomarker Response" calculation based on reference deviation concept. Environ. Sci. Pollut. Res. Int. 20 (5), 2721-2725.

Sánchez-Muros, A.J., Villacreces, S., Lama, G.M., Haro, C., Garcíabarroso, F., 2013. Effects of chemical and handling exposure on fatty acids, oxidative stress and morphological welfare indicators in gilt-head sea bream (Sparus aurata). Fish. Physiol. Biochem. 39, 581-591.

Scheil, V., Kienle, C., Osterauer, R., Gerhardt, A., Köhler, H., 2009. Effects of 3,4-dichloroaniline and diazinon on different biological organization levels of zebrafish (Danio rerio) embryos and larvae. Ecotoxicology 18, 355-363.

Schlenk, D., Lavado, R., Loyo-Rosales, J., Jones, W., Maryoung, L., Riar, N., Werner, I. Sedlak, D., 2012. Reconstitution studies of pesticides and surfactants exploring the cause of estrogenic activity observed in surface waters of the San Francisco Bay Delta Environ. Sci. Technol. 46, 9106-9111.

Schoket, B., Vincze, I., 1990. Dose-related induction of rat hepatic drug-metabolizing enzymes by diuron and chlorotoluron, two substituted phenylurea herbicides. Toxicol. Lett. 50 (1), 1-7.

Sies, H., Koch, O.R., Martino, E., Boveris, A., 1979. Increased biliary glutathione disulfide release in chronically ethanol-treated rats. FEBS Lett. 103, 287-290.

Sosak-Swiderska, B., Tyrawska, D., Maslikowska, B., 1998. Microalgal ecotoxicity test with 3,4-dichloroaniline. Chemosphere 37, 2975-2982.

Stegeman, J.J., Brouwer, M., Richard, T.D.G., Förlin, L., Fowler, B.A., Sanders, B.M., van Veld, P.A., 1992. Molecular responses to environmental contamination: enzyme and protein systems as indicators of chemical exposure and effect. In: Huggett, R.J., Kimerly, R.A., Mehrle JrP.M., Bergman, H.L. (Eds.), Biomarkers: Biochemical, Physiological and Histological markers of Anthropogenic Stress. Lewis Publishers, Chelsea, MI, USA, pp. 235-335.

Sydow, K., Daiber, A., Oelze, M., Chen, Z., August, M., Wendt, M., Ullrich, V., Mülsch, A., Schulz, E., Keaney, J.F., Jr, Stamler, J.S., Münzel, T., 2004. Central role of mitochondrial aldehyde dehydrogenase and reactive oxygen species in nitroglycerin tolerance and cross-tolerance. J. Clin. Investig. 113 (3), 482-489.

Tixier, C., Bogaerts, P., Sancelme, M., Bonnemoy, F., Twagilimana, L., Cuer, A., Bohatier, J., Veschambre, H., 2000. Fungal biodegradation of a phenylurea herbicide, diuron: structure and toxicity of metabolites. Pest Manag. Sci. 56, 455-462.

Tixier, C., Sancelme, M., Ait-Aissa, S., Widehem, P., Bonnemoy, F., Cuer, A., Truffaut, N., Veschambre, H., 2002. Biotransformation of phenylurea herbicides by a soil bacterial strain, Arthrobacter sp. N2: structure, ecotoxicity and fate of diuron metabolite with soil fungi. Chemosphere 46, 519-526.

Tixier, C., Sancelme, M., Bonnemoy, F., Cuer, A., Veschambre, H., 2001. Degradation products of a phenylurea herbicide, diuron: synthesis, ecotoxicity, and biotransformation. Environ. Toxicol. Chemistry20 7, 1381-1389.

Trivic, S., Leskuvac, V., 1994. Kinect mechanism of yeast alcohol dehydrogenase with primary aliphatic alcohols and aldehydes. Biochem. Mol. Biol. Int. 32, 399-407.

Troiano, J., Weaver, D., Marade, J., Spurlock, F., Pepple, M., Nordmark, C., Bartkowiak, D., 2001. Summary of well water sampling in California to Detect pesticide residues resulting from Nonpoint-source applications. J. Environ. Qual. 30, 448-459.

UNICA, 2016. União da Indústria de Cana-de-Açúcar. Etanol de cana-de-açúcar. Available in: 〈http://www.unica.com.br 〉. (Accessed 20 November 2016).

Van der Oost, R., Beyer, J., Vermeulen, N.P.E., 2003. Fish bioaccumulation and biomarkers in environmental risk assessment: a review. Environ. Toxicol. Pharmacol. 13, 57-149.

Zar, J.H., 1999. Biostatistical Analysis, 4th ed. Prentice Hall, Upper Saddle River, NJ, pp. 960.

Zhao, B., Baston, D.S., Hammock, B., Denison, M.S., 2006. Interaction of diuron and related substituted phenylureas with the Ah receptor pathway. J. Biochem. Mol. Toxicol. 20 (3), 103-113. 